\title{
Distribution of building-associated wood-destroying fungi in the federal state of Styria, Austria
}

\author{
Doris Haas $^{1}\left(\mathbb{0} \cdot\right.$ Helmut Mayrhofer ${ }^{2} \cdot$ Juliana Habib $^{1} \cdot$ Herbert Galler $^{1} \cdot$ Franz Ferdinand Reinthaler $^{1}$. \\ Maria Luise Fuxjäger ${ }^{3}$. Walter Buzina ${ }^{1}$
}

Received: 20 September 2018 / Published online: 5 April 2019

(c) The Author(s) 2019

\begin{abstract}
Wood is an important construction material, but when used incorrectly it can be subjected to deterioration by wood-destroying fungi. The brown rot producing dry rot fungus (Serpula lacrymans) is by far the most dangerous wood-destroying fungus in Europe. In the present publication, 645 fungal samples from damaged wood in the federal state of Styria (Austria) were examined and recorded by isolation date, geographical location, species identification of the wood-destroying fungus, location of damage, construction method, and age and type of building. In Styria, Serpula spp. accounted for $61.5 \%$ of damages, followed by Antrodia spp. (10.7\%) and the genera Gloeophyllum (8.2\%), Coniophora (3.9\%) and Donkioporia (1.1\%). Properties in the area of the Styrian capital Graz and old buildings were more often infested by wood-destroying fungi than houses in the rural area and new constructions.
\end{abstract}

\section{Introduction}

Wood rot is the degradation of wood by the destruction of organic materials caused by fungi. This process is predominantly affected by temperature and moisture as well as the durability of wood material (Krzisnik et al. 2018). Wood decaying fungi can be divided into brown rot, white rot and soft rot. Up to now, 120 different wood-destroying fungi in buildings have been identified in central Europe (Huckfeldt and Schmidt 2015). The fungus that causes the most severe damages to European buildings in service is the brown rot producing dry rot fungus (Serpula lacrymans), which was recently ranked as one of the world's ten most feared fungi (Hyde et al. 2018).

Wood still ranks among the leading construction materials in Europe because of its high load capacity, good thermal insulation, stability as well as low carbon footprint. However, when wood is not protected properly, insects and wood degrading fungi such as the dry rot fungus (S. lacrymans),

Doris Haas

doris.haas@medunigraz.at

1 D\&R Institute of Hygiene, Microbiology and Environmental Medicine, Medical University Graz, Graz, Austria

2 Institute of Plant Sciences, University of Graz, Graz, Austria

3 Bureau Marialuise Fuxjaeger, Graz, Austria the cellar fungus (Coniophora puteana), Antrodia spp. and other wood-destroying fungi can cause severe damage to buildings and potentially cause human injuries. Some wooddestroying fungi can penetrate even masonry and are able to translocate water and nutrition over long distances.

Infestations of buildings with wood-destroying fungi can have different causes: contaminated construction wood, ingress of fungal spores into the building, or usage of fungus-infested timber. Precondition for the development of every fungal infestation is humidity, aerobic conditions facilitate the growth of wood-destroying fungi. Under appropriate conditions, fungal spores germinate and develop hyphae that colonize large areas. Infestations with wood-destroying fungi are often not recognized at an early stage because of the hidden nature of growth (behind wall paneling, under floorboards etc.). The mycelium continues to grow as long as there is enough nutrition available, thereafter, fruiting bodies are produced which form numerous spores. Adequate humidity and temperature are mandatory for the growth of wood-destroying fungi. Therefore, climatic changes may be an important factor for an increased occurrence. When a wood-destroying fungus has spread in a building, an accurate diagnosis of the nature of the fungus is mandatory for reliable estimate of the damage and proper renovation/restoration. Wood-destroying fungi can be substrate-specific species, which rely on certain wood, or unspecific, which can grow on different kinds of wood (Bavendamm 1969; 
Plank 1979; Schwarze 2007). In Northern Europe, mainly conifers are used as construction material. Hence, fungal species adapted to conifers like the genera Serpula, Antrodia and Coniophora are found to cause the majority of damages in buildings in this region (Schmidt 2010).

According to Dämon et al. (2000), a variety of wooddestroying fungi occurs in the federal state of Styria, depicted in a mycological map of "Weststeiermark". Maurer et al. (2009) conducted a mycological mapping of the montane and subalpine altitude zones of "Obersteiermark" and found 500 wood-destroying fungal species, S. lacrymans once from a disposed spruce board on a forest edge. In Styria, S. lacrymans is the most widespread wood-destroying fungus in buildings. Building-associated records (covering more than four decades) are present of almost all political districts of Styria (Mayrhofer 2006). The infestation of buildings with $S$. lacrymans is estimated in a scale of 1000-2500 incidents annually according to IBO (Österreichisches Institut für Baubiologie und Bauökologie, Austrian Institute for Construction Biology and Ecology). These numbers are subject to considerable fluctuations because of, for example, changing weather events or flooding. In the past, it was mandatory to report the presence of $S$. lacrymans to the authorities in Austria, but not at the present time (Kalcher 2004), whereas, for example, in Germany, a reporting obligation still exists in some states (Thuringia, Hesse, Saarland, Hamburg and Saxony). However, in the case of an infestation of a building with wood-destroying fungi there are regulations and norms in Austria dealing with compulsory measures for damage management and control strategies.

The abatement and damage-abolition have to be performed by a specialized company based on an expert opinion (Behling 2004). In the case of wood-destroying fungi, there is the demand to differentiate between infestations by $S$. lacrymans and those by other wood-destroying fungi, because in the first case much more elaborate renovation measures are necessary.

So far, there have been no reports existing on the prevalence and incidence of wood-destroying fungi in buildings in different regions of the federal state of Styria/Austria. The goal of this study was to provide an overview on the frequency of wood-destroying fungi in different buildings and construction categories for this region.

\section{Materials and methods}

\subsection{Data acquisition of fungi}

From all 645 cases collected in Styria, fungal species, type of rot (brown or white rot), location of the damage, construction method, age (new: after 1945) and type of building (cultural monument or residential building, detached or apartment building), isolation date, place and geographical region were recorded. Fungi identified at the Institute of Hygiene, Microbiology and Environmental Medicine, Medical University Graz (IHMU), were collected and preserved as illustrative material and for documentation of the local biodiversity of wood-destroying fungi in Styria.

Styria with its capital Graz is the second largest $\left(16,401 \mathrm{~km}^{2}\right)$ federal state in Austria, located in the southeast of the country, and around $61 \%$ of the area is forested. The north of Styria is alpine, the south mainly hilly and covered with meadows, pastures, crops as well as fruit orchards and vineyards. Styria is subdivided into seven regions and has more than 1.2 million inhabitants (01.01.2018, Statistik Austria 2018).

\subsection{Identification of fungi}

The identification of samples was primarily done by macroscopic characteristics. In wood-decaying fungi, these are specific surface mycelia, strands and fruiting bodies. Particularly important features are size, color and consistency of the fungus, texture and decay pattern of the wood (cubical cracking), depth of hyphal penetration, and also type (brown rot, white rot and soft rot) and intensity of wood rot (Weiss et al. 2000). When macroscopic diagnosis was inconclusive, microscopic identification took place. Therefore, identification keys were used together with microscopy (Gistl 1946; Huckfeldt and Schmidt 2015). If morphological examination did not lead to an unambiguous result as was the case in 177 samples, molecular methods (PCR, sequencing of the ITS region of ribosomal DNA) were used (Gardes and Bruns 1993; Schmidt 2000; Högberg and Land 2004). Identification based on the sequence data was carried out using BLAST (http://blast.ncbi.nlm.nih.gov) and GenBank (http:// www.ncbi.nlm.nih.gov/genbank).

\section{Results}

Altogether 645 damage surveys were collected. Thereof 296 samples were examined at the IHMU, and data of 349 damage cases were provided by other institutions throughout Styria. Among all diagnosed wood-destroying fungi, 74 genera and 40 species were differentiated (Table 1).

\subsection{Wood-destroying fungi by years}

The occurrence of wood-destroying fungi in the years before 1980-2016 is listed in 10-year intervals (Table 2). From 645 collected fungi, 397 (61.5\%) were Serpula spp., followed by Antrodia spp. (69/10.7\%) and the genera Gloeophyllum (53/8.2\%), Coniophora (25/3.9\%) and Donkioporia (7/1.1\%) (Table 2). 
Table 1 Spectrum of wood-destroying fungal species

\begin{tabular}{|c|c|c|}
\hline Genera and species & $\mathrm{n}$ & $\%$ \\
\hline Antrodia serialis & 3 & 0.5 \\
\hline A. sinuosa & 1 & 0.2 \\
\hline A. vaillantii & 5 & 0.8 \\
\hline A. xantha & 7 & 1.1 \\
\hline Antrodia sp. & 53 & 8.2 \\
\hline Bjerkandera adusta & 1 & 0.2 \\
\hline Coniophora marmorata & 1 & 0.2 \\
\hline C. puteana & 16 & 2.5 \\
\hline Coniophora sp. & 8 & 1.2 \\
\hline Coprinopsis sp. & 1 & 0.2 \\
\hline Coprinus patouillardii & 1 & 0.2 \\
\hline Crustoderma dryinum & 1 & 0.2 \\
\hline Cylindrobasidium evolens & 1 & 0.2 \\
\hline Donkioporia expansa & 7 & 1.1 \\
\hline Fomes fomentarius & 1 & 0.2 \\
\hline Fomitopsis pinicola & 1 & 0.2 \\
\hline Ganoderma sp. & 1 & 0.2 \\
\hline Gloeophyllum abietinum & 8 & 1.2 \\
\hline G. sepiarium & 18 & 2.8 \\
\hline G. trabeum & 6 & 0.9 \\
\hline Gloeophyllum sp. & 21 & 3.3 \\
\hline Hyphodontia sambuci & 1 & 0.2 \\
\hline Leucogyrophana mollusca & 1 & 0.2 \\
\hline L. pinastri & 4 & 0.6 \\
\hline Neolentinus lepideus & 2 & 0.3 \\
\hline Penidiella kurandae & 1 & 0.2 \\
\hline Pestalotiopsis protearum & 1 & 0.2 \\
\hline Peziza varia & 2 & 0.3 \\
\hline Pylotopsis nidulans & 1 & 0.2 \\
\hline Pluteus cervinus & 1 & 0.2 \\
\hline Polyporus sp. & 7 & 1.1 \\
\hline Resinicium bicolor & 2 & 0.3 \\
\hline Rhodonia placenta & 3 & 0.5 \\
\hline Rigidoporus vitreus & 1 & 0.2 \\
\hline Schizopora radula & 1 & 0.2 \\
\hline Scytalidium lignicola & 2 & 0.3 \\
\hline Serpula himantioides & 2 & 0.3 \\
\hline Serpula lacrymans & 395 & 61.2 \\
\hline Stereum hirsutum & 1 & 0.2 \\
\hline Talaromyces radicus & 1 & 0.2 \\
\hline Tapinella panuoides & 2 & 0.3 \\
\hline Trametes abietina & 1 & 0.2 \\
\hline T. hirsuta & 1 & 0.2 \\
\hline T. trogii & 2 & 0.3 \\
\hline Trametes sp. & 3 & 0.5 \\
\hline Trechispora farinacea & 2 & 0.3 \\
\hline Trechispora sp. & 1 & 0.2 \\
\hline Tyronectria viriens & 1 & 0.2 \\
\hline Other genera & 41 & 6.4 \\
\hline Sum & 645 & 100.0 \\
\hline
\end{tabular}

\subsection{Wood-destroying fungi by region}

Based on the addresses of damage events, it is possible to show the distribution of wood-destroying fungi in the seven regions of Styria (Fig. 1). The highest number $(342 / 53.0 \%)$ was found in "Steirischer Zentralraum" which also includes the Styrian capital Graz (273/42.3\%), the lowest number in Liezen $(22 / 3.4 \%)$. The frequency of wood-destroying fungi by region is listed in Table 3 .

Serpula spp. were by far the most prevalent wooddestroying fungi in Styria. There exist 397 (61.5\%) records (395 S. lacrymans and two S. himantioides). In "Liezen", S. lacrymans was found 14 times, in "Steirischer Zentralraum" 204 times, alone in the city of Graz 165 times. The "wild relative" of $S$. lacrymans, $S$. himantioides, was documented twice in the present study in "Südweststeiermark" and "Steirischer Zentralraum".

Strand mycelia or fruiting bodies of Antrodia spp. were found in 69 cases (10.7\%) in Styrian buildings. From "Steirischer Zentralraum", 36 cases were reported, among them 29 from Graz, whereby three different species ( $A$. sinuosa, A. vaillantii, A. xantha) were identified. Antrodia spp. were also found in the hilly districts of "Oststeiermark" (5) and in the mountainous regions of "Obersteiermark" (13), whereby A. serialis was found as well besides the above mentioned species.

Gloeophyllum spp. are widespread in Styria, 53 isolates $(8.2 \%)$ were documented. They were found in the first place in "Steirischer Zentralraum" (36), whereby $G$. sepiarium was predominant in "Steirischer Zentralraum" and G. trabeum in "Obersteiermark".

Coniophora spp., mainly C. puteana, were documented 25 times (3.9\%) in Styria, and one single specimen of $C$. marmorata was reported from an apartment building in Graz ("Steirischer Zentralraum").

The white-rot fungus Donikioporia expansa was found for the first time in Styria in 2007 in "Liezen", since then D. expansa was discovered as well in other regions, in total 7 times $(1.1 \%)$.

Altogether 94 sites (14.6\%) with other wood-destroying fungi were documented in Styria, mainly in "Steirischer Zentralraum" (47, Graz 34), "Obersteiermark West" (13) and "Obersteiermark Ost" (11). Fomitopsis pinicola, Coprinus parouillardi and Peziza varia were detected in urban areas in apartment buildings. Rhodonia placenta (formerly Postia or Oligoporus placenta) grew in the city of Graz ("Steirischer Zentralraum"), in "Obersteiermark Ost" in an historical building and in "Obersteiermark West" in a mountain hut. Resinicium bicolor was isolated in "Oststeiermark" and "Obersteiermark Ost". From the wood-destroying genus Trametes, the species T. abietina was identified in urban areas, and T. trogii in 
Table 2 Chronological occurrence of the 5 most common wood-destroying fungal genera in Styria

\begin{tabular}{lrrrrrrr}
\hline Genera & $<1980$ & $1980-1989$ & $1990-1999$ & $2000-2009$ & $2010-2016$ & Sum & $\%$ \\
\hline Serpula & 12 & 14 & 155 & 106 & 110 & 397 & 61.5 \\
Antrodia & 1 & 0 & 11 & 21 & 36 & 69 & 10.7 \\
Gloeophyllum & 2 & 1 & 7 & 13 & 30 & 53 & 8.2 \\
Coniophora & 0 & 0 & 5 & 9 & 11 & 25 & 3.9 \\
Donkioporia & 0 & 0 & 0 & 3 & 4 & 7 & 1.1 \\
Other fungi & 2 & 3 & 15 & 23 & 51 & 94 & 14.6 \\
Sum & 17 & 18 & 193 & 175 & 242 & 645 & 100.0 \\
\hline
\end{tabular}

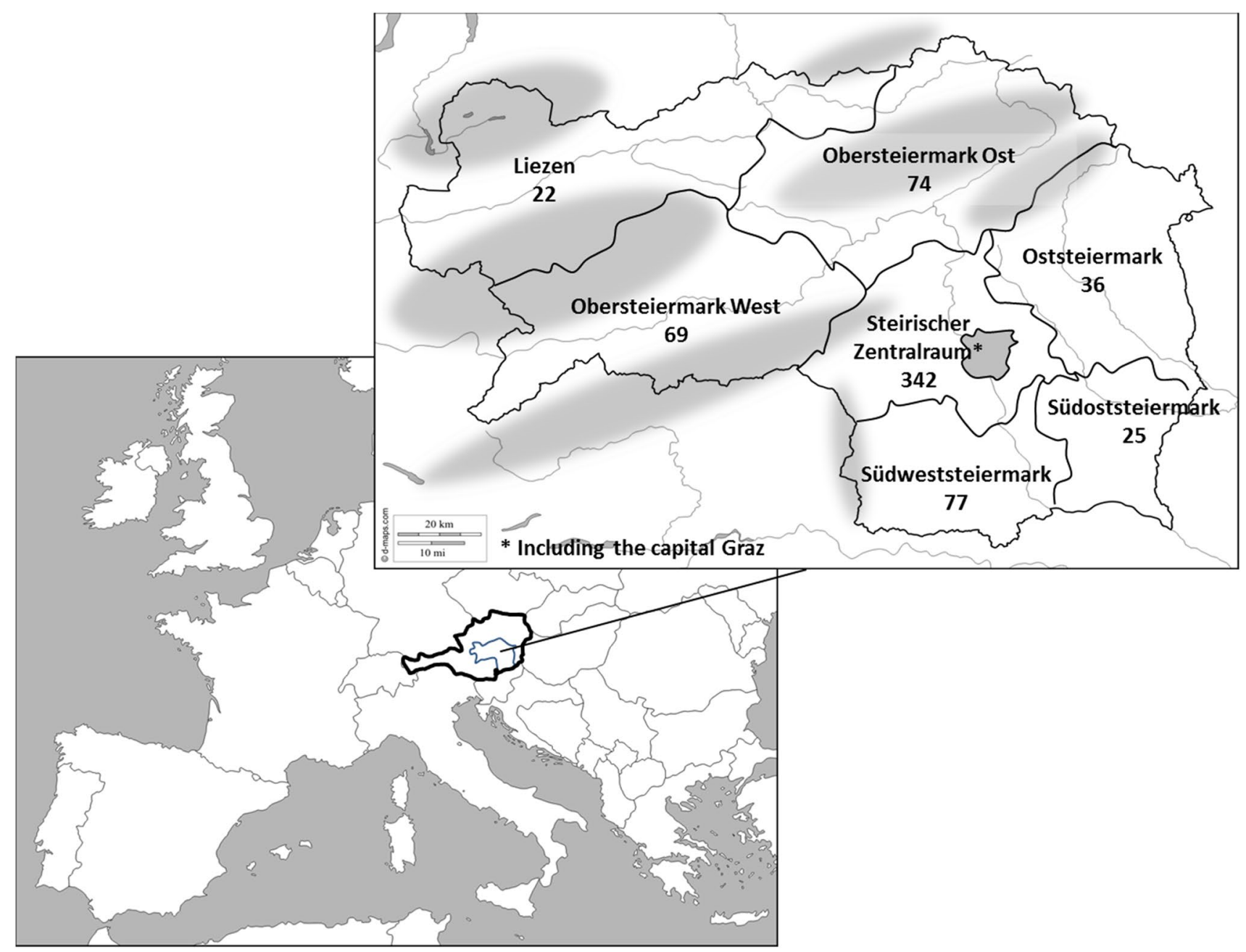

Fig. 1 Number of wood-destroying fungi in the seven regions and their localization in Styria, Austria

"Obersteiermark Ost". Leucogyrophana pinastri and $L$. mollusca were found once each in wooden huts.

\subsection{Wood-destroying fungi by construction categories}

The prevalence of wood-destroying fungi in different buildings was grouped in these categories: old buildings (before 1945) and new buildings, cultural buildings and residential buildings, single-family houses and apartment buildings (listed in Table 4).

Wood-destroying fungi were found more frequently in old buildings (530/82.1\%) than in new buildings (115/17.9\%). S. lacrymans occurred in old buildings 351 times $(88.4 \%)$, in new buildings 46 times (11.6\%). 
Table 3 Frequency of wooddestroying fungi $(n=645)$ in the 7 Styrian regions

\begin{tabular}{|c|c|c|c|c|c|c|c|}
\hline \multirow[t]{2}{*}{ Region } & \multicolumn{6}{|c|}{ Frequency } & \multirow[t]{2}{*}{ Sum } \\
\hline & $\begin{array}{l}\text { Serpula } \\
61.5 \%\end{array}$ & $\begin{array}{l}\text { Antrodia } \\
10.7 \%\end{array}$ & $\begin{array}{l}\text { Gloeophyllum } \\
8.2 \%\end{array}$ & $\begin{array}{l}\text { Coniophora } \\
3.9 \%\end{array}$ & $\begin{array}{l}\text { Doniki- } \\
\text { oporia } \\
1.1 \%\end{array}$ & $\begin{array}{l}\text { Other } \\
14.6 \%\end{array}$ & \\
\hline Liezen & 14 & 2 & 0 & 2 & 1 & 3 & 22 \\
\hline Obersteiermark Ost & 44 & 7 & 7 & 2 & 3 & 11 & 74 \\
\hline Obersteiermark West & 49 & 6 & 0 & 1 & 0 & 13 & 69 \\
\hline Oststeiermark & 18 & 5 & 5 & 2 & 0 & 6 & 36 \\
\hline Steirischer Zentralraum & 205 & 36 & 36 & 15 & 3 & 47 & 342 \\
\hline Südoststeiermark & 15 & 4 & 3 & 1 & 0 & 2 & 25 \\
\hline Südweststeiermark & 52 & 9 & 2 & 2 & 0 & 12 & 77 \\
\hline Sum & 397 & 69 & 53 & 25 & 7 & 94 & 645 \\
\hline
\end{tabular}

Table 4 Distribution of wood-destroying fungi in different types of houses in Styria and the capital Graz (in parentheses)

\begin{tabular}{|c|c|c|c|c|c|c|}
\hline Genera & Old buildings $\mathrm{s}^{\mathrm{a}}$ & New buildings & Cultural buildings & Residential buildings & $\begin{array}{l}\text { Single-family } \\
\text { houses }\end{array}$ & Apartment buildings \\
\hline Serpula & $351(153)$ & $46(12)$ & $62(3)$ & 335 (162) & $234(49)$ & $163(116)$ \\
\hline Antrodia & $55(22)$ & $14(6)$ & $9(0)$ & $60(28)$ & $39(9)$ & $30(19)$ \\
\hline Gloeophyllum & $31(13)$ & $22(14)$ & $4(0)$ & $49(27)$ & $31(15)$ & $22(12)$ \\
\hline Coniophora & $21(12)$ & $4(2)$ & $0(0)$ & $25(14)$ & $10(2)$ & $15(12)$ \\
\hline Donkioporia & $4(2)$ & $3(1)$ & $0(0)$ & $7(3)$ & $2(0)$ & $5(3)$ \\
\hline Others & $68(24)$ & $26(12)$ & $18(3)$ & $76(33)$ & $59(11)$ & $35(25)$ \\
\hline
\end{tabular}

${ }^{a}$ Old buildings: constructed before 1945

\subsection{Wood-destroying fungi by sampling location}

The substrate of the investigated wood-destroying fungi was mostly processed wood within infested buildings. Most of the fungi were isolated from wood in cellars and the roof, or from support beams and floors. The type of wood was above all spruce (Picea abies), oak (Quercus spp.) and pine (Pinus sylvestris). Figure 2 illustrates the location of the wood decaying fungi.

Serpula spp., in particular S. lacrymans was found most frequently on or in floors and in cellar rooms (Fig. 2). Its close relative $S$. himantioides was isolated twice, once on a rotten floor of spruce wood in a farmhouse and once on spruce flooring in a multistory building in the city.

Antrodia spp. grow on coniferous wood and destroy mainly wood in roof frames and ceiling constructions, as was the case by A. xantha and A. sinuosa. A. serialis appeared in the floor in cellars, and A. vaillantii in wet rooms. In some churches in Styria, this fungus infested the wood of pedestals from pews.

Gloeophyllum spp. occurred in roofs, windows and door constructions, as well as on wood on terraces and balconies. While G. sepiarium and G. trabeum were more frequently found in attics, G. abietinum preferred window and door frames.
True to its name, locations of the cellar fungus Coniophora puteana were mainly cellar walls and floors, above all those with contact to the earth. This fungus was rarely found in attics or on ceiling beams. The only finding site of $C$. marmorata was a brick floor in a cellar in Graz.

Donkioporia expansa infested heavily soaked parts of floors and beams in old buildings, producing white rot.

Besides the five most common genera of wood-destroying fungi in Styria, many other fungi were identified, as shown in Table 1. They occur mainly in ceiling beams or on floors of single-family houses and apartment buildings. In such a manner, specific genera of wood-destroying fungi may correlate to certain parts of a building: Coriolopsis, Peziza, Resinicium, Tapinella and Trametes occur in floors, Rhodonia, Trechispora and Trametes in wooden walls and beams, Pluteus in cellars. In wooden attics or on ceiling beams, the following wood-decaying fungi were found: Penidiella, Phylotopsis, Resinicium, Pestalotiopsis, Rigidoporus, Schizopora, Scytalidium and Talaromyces. Leucogyrophana pinastri has grown in two buildings on the spruce floor in a castle and on the basement ceiling of a farmhouse. Leucogyrophana mollusca was discovered in an alpine wooden house on floors and walls. 

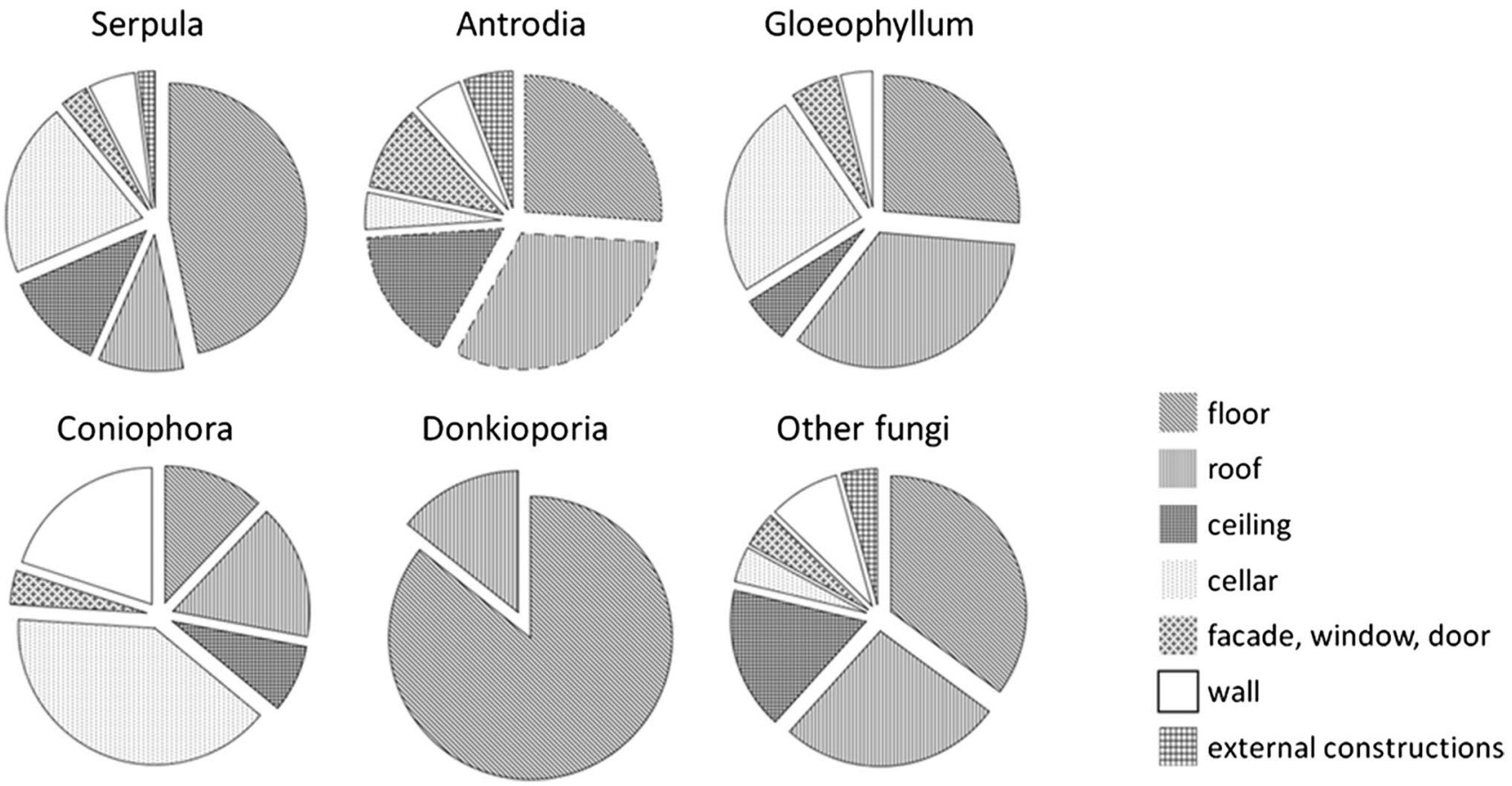

Fig. 2 Wood-destroying fungi by sampling location

\section{Discussion}

The data of this study offer a first overview on the distribution and spectrum of wood-destroying fungi in Styria, but it is by no means comprehensive.

"Dry rot" was first mentioned in 1765 , when devastation of construction wood became a serious problem (Singh 1999). Some of the wood-destroying fungi were transported from one country to another through timber imports (Weir 1919). Because $S$. lacrymans has the highest destructive potential and occurs quite frequently, this fungus is in the focus of most of the studies concerning wood-destroying fungi. According to the Austrian national heritage agency (Bundesdenkmalamt), up to 200 renovation cases are reported every year in Styria. S. lacrymans is widely distributed in Styria and up to now, 397 reports from different regions exist. S. lacrymans occurs more frequently in mountainous regions and in the city of Graz than in the hilly southern regions. The hot spots of S. lacrymans in Germany are North Rhine-Westphalia and the cities Hamburg and Munich (Buchwald 1989). In Finland, 110 wood-destroying fungi (59\% S. lacrymans) were diagnosed between 1978 and 1984, and 116 cases between 1985 and 1988 (43\% S. lacrymans) (Paajanen and Viitanen 1989). During the period of 1996-2002, S. lacrymans was the most frequent wooddestroying fungus in Latvian buildings with $46.7 \%$ (Irbe and Andersone 2009). In a study by Pilt et al. (2009), 633 damage cases were reported in Estonian buildings between 2002 and 2008. In these cases, S. lacrymans was also most frequently isolated (502 cases, 79.3\%). Second was C. puteana (7.0\%), followed by Antrodia spp. (5.3\%) (Pilt et al. 2009). In Norway the most commonly found brown rot producing fungi were $C$. puteana $(16.3 \%)$ and S. lacrymans (16.0\%), whereas in Finland Antrodia spp. were more prevalent (Alfredsen et al. 2005). In the present study, 40 different species from 74 genera of wood-destroying fungi were identified in Styrian buildings. This is, compared to Estonia with 16 species, quite a high number. The sum of 35 species of wood-destroying fungi was reported from 1428 building investigations in Norway (Pilt et al. 2009; Alfredsen et al. 2005). Schmidt (2007) described 80 wood-destroying basidiomycetes that commonly occur in German buildings.

The dry rot fungus $S$. lacrymans, on the one hand, is able to adjust to the environment, therefore it is present worldwide, but on the other hand, it needs specific parameters to survive and grow in buildings (Maurice et al. 2011). It can be found in Europe as well as in cold regions in Asian countries. Engh et al. (2010) have found significant genetical differences between European and Japanese isolates. Genetical data led to the conclusion that the evolutionary origin of $S$. lacrymans is in the Himalayas (Kauserud et al. 2007; Skrede et al. 2011). Kauserud (2004) demonstrated the occurrence of geographically widespread vegetative compatibility groups in S. lacrymans in Europe. In a recently published review by Gabriel and Svec (2017), the authors report $S$. lacrymans to be the most abundant wood decaying fungus in the following European countries: Poland, Germany (both former FRG and GDR), Belgium, Latvia, Finland and 
Estonia, and the second most common in Denmark, Norway and Romania. S. lacrymans has also spread over New Zealand and southern Australia (Thornton 1991), as well as over central and northern America (Watkinson and Eastwood 2012). According to Palfreyman (2001), S. lacrymans has not been reported from tropical countries. The distribution of $S$. himantioides is unclear in many places. It was recorded from central and northern Europe, northern Asia, northern America, southern Australia and New Zealand (Kauserud et al. 2004, GBIF 2017). In France, S. himantioides is often in close association with D. expansa (Pottier et al. 2014). In contrast to $S$. lacrymans, S. himantioides grows in nature and only rarely in buildings (Maurer et al. 2014; Palfreyman et al. 2003). In the present study, S. himantioides was found in a farmhouse and in a multistory building in the city. Maurer et al. (2013) have reported on the occurrence of this fungus once on a disposed spruce board and once on a board in a stream bed. Two species of Serpula, namely $S$. lacrymans and S. himantioides from Himalayan forests, were first successfully cultured and identified in 1997 (White et al. 1997, 2001).

Investigations of more than 5000 damage reports in Germany have shown that all wooden structures in buildings can be a substrate for wood-destroying fungi when the wood is not protected properly (Schmidt 2007). Areas of particular interest are the implications of wood-destroying fungi on buildings with different construction methods, softwood and hardwood timbers, and location of the damage site.

On average 0.4 damage cases per 1000 inhabitants were reported in the present study in rural areas and small towns (Styria without Graz) but 1.0/1000 inhabitants in the capital Graz (Table 5). This above-average accumulation of wooddestroying fungi, above all S. lacrymans, in the city of Graz, may be explained by the fact that Graz suffered from massive

Table 5 Cases of damages by wood-destroying fungi per region and population numbers from 2017 (modified after Statistik Austria)

\begin{tabular}{llll}
\hline Region & Population 2017 & $\begin{array}{l}\text { Wood- } \\
\text { destroying } \\
\text { fungi }\end{array}$ & $\begin{array}{l}\text { Cases per } \\
1000 \text { resi- } \\
\text { dents }\end{array}$ \\
\hline Liezen & 80,011 & 22 & 0.3 \\
Obersteiermark Ost & 160,777 & 74 & 0.5 \\
Obersteiermark West & 101,006 & 69 & 0.7 \\
Oststeiermark & 180,299 & 36 & 0.2 \\
Südoststeiermark & 86,044 & 25 & 0.3 \\
Südweststeiermark & 142,556 & 77 & 0.5 \\
Steirischer Zen- & 202,736 & 69 & 0.4 \\
$\quad$ tralraum (without & & & \\
$\quad$ Graz) & & 273 & 1.0 \\
Graz & 283,869 & 372 & 0.4 \\
Styria without Graz & 953,429 & 645 & 0.5 \\
Styria complete & $1,237,298$ & &
\end{tabular}

damages by aircraft bombs during the "Second World War (WW2)". In 57 bombing raids between 1939 and 1945, a total of 7743 buildings were destroyed or damaged in Graz, 8999 apartments were made unusable and 11,065 apartments were damaged. In total, 3707 tons of bombs were thrown on Graz, almost 2000 people (1\% of the population) died, and an estimate number of 1500 people was injured (Brunner 1989). Consequently many damaged buildings remained exposed unprotected to all types of weather for years, before reconstruction began, mostly without antifungal preservation. Furthermore, fungus-infested construction wood was most likely brought as firewood into undamaged buildings. For many buildings in Graz, where S. lacrymans has been found up to the present, bombing damages during WW2 are documented.

According to Huckfeldt et al. (2011), S. lacrymans mostly occurs under floor boards, in the ceiling or under poorly sealed bathrooms or leaking pipes, but infrequently in attics. The authors reported $S$. lacrymans both in new and old buildings. In the present study, this fungus was found mostly in old buildings $(88.4 \%)$. In new buildings, the incorporation of moist or infested wood or inadequate drying out of buildings can lead to the development of damages caused by wood-destroying fungi. In this study, S. lacrymans was found in floors in $46.6 \%$ of cases. In a Norwegian survey, $S$. lacrymans was responsible for damages in the floor in $17.0 \%$ and in walls in $17.1 \%$ (Alfredsen et al. 2005).

The second most frequently isolated wood-destroying fungal genus was Antrodia. A. serialis infested cellars and wooden floors (garden hut), A. sinuosa preferred roof beams in old buildings, and A. vaillantii chipboards in new buildings. In Styrian monasteries and churches, A. xantha was found in roof frames and beams. The wooden ceiling of an indoor swimming pool was also subject of damage by an Antrodia species. In Europe, the most common species of Antrodia is A. vaillantii, which occurs preferably in spruce wood (Schmidt 1994). A. sinuosa is found in Europe, northern America and Australia on coniferous wood (Schmidt 2010). Antrodia was the most frequent genus of fungi in Norwegian roof beams (17.3\%), in roof and wall constructions (28.6\%) and in exterior constructions (Alfredsen et al. 2005; Gabriel and Svec 2017). A. serialis was only found sporadically in buildings from other countries (Schmidt 1994). Maurer et al. (2009) discovered A. serialis in the montane, subalpine region of Styria. The yellow pore fungus $A$. xantha was found on windows, swimming pools and flat roofs (Schmidt 1994).

Gloeophyllum comprises three important wood-destroying species, which are found widespread in Europe, in North America, northern Africa and Asia. G. abietinum is the most common species and prefers the wood of spruce and fir. In the present study, it was mostly found in urban areas on outdoor wooden constructions. This is consistent with findings 
from other studies where this fungus is described as common destroyer of weathered hardwood constructions, when sufficient moisture and warming sunlight is present (Pfabigan 2011; Schmidt et al. 2002). G. abietinum occurs in northern regions, and frequently destroys wooden windows, whereas the quite rare G. trabeum is commonly found in the south and prefers deciduous wood (Schmidt 1994). According to Plank (1979), G. odoratum is connected to spruce wood, $G$. sepiarium also grows on fir and pine wood, which is commonly used as construction material. Molecular and biological investigations proved the occurrence of $G$. trabeum, $G$. abietinum and G. sepiarium (rusty gilled polypore) in buildings in Germany (Schmidt et al. 2002). These three species are important destroyers of wooden windows and are often found in the attics of buildings. In the present study, these three Gloeophyllum spp. were found as well. G. abietinum was isolated in a higher number from windows and doorframes, as well as from balconies and terraces, G. sepiarium was present on wood in the exterior area of mountain huts, on terraces, fences and roofs in urban buildings, and $G$. trabeum on wooden constructions in the roof, on floors and in wet areas. G. sepiarium was found in Norwegian buildings in floors $(1.5 \%)$, in walls $(1.9 \%)$, in roofs $(6.0 \%)$, on window- and doorframes (1.9\%), and mostly in external areas of buildings (13.2\%). G. trabeum was not reported from Norwegian buildings, but in Finland, this species was found together with G. sepiarium, the former mainly in saunas and from roof beams (Alfredsen et al. 2005). The increase in Gloeophyllum spp. in Denmark was traced back by Koch (1991) to the fact that window and roof constructions are often deficient (Schmidt 2010), others claim that the rise of $G$. sepiarium on window frames is a consequence of the introduction of thermo-windows (Alfredsen et al. 2005).

Coniophora is present in Europe with 12 species, of which five are regularly found in the environment (Huckfeldt and Schmidt 2015). The wet or cellar rot C. puteana is by far the most frequent species within this genus. $C$. puteana occurs mainly in new buildings, but also in old buildings, it can spread over the whole object, from cellar to roof (Grosser 1985; Schmidt and Huckfeldt 2011). This fungus proliferates in moist walls with cracks, occurs under boards in kitchens and bathrooms but can also develop outdoors on masts, poles and windows. In Denmark and Romania, $C$. puteana was the most commonly isolated wood-destroying fungus in buildings (Gabriel and Svec 2017). This fungus was also present in walls $(14.4 \%)$, on roofs $(11.3 \%)$, on window and door frames $(15.5 \%)$ and in external constructions (19.8\%) (Alfredsen et al. 2005). C. puteana was also found in historical buildings on "Deception Island" in Antarctica (Held and Blanchette 2017). In the present study, Coniophora spp. did not occur in historical buildings. Sterflinger (2010) described $C$. puteana together with S. lacrymans in churches, when wooden altars or roofs are defect.
Of the other species, only $C$. marmorata was recorded once in a cellar floor of an apartment building in this study. In Denmark, $C$. marmorata is found quite frequently in buildings after water leakage. Krieglsteiner (1991) documented C. marmorata for former Western German States. C. prasinoides, which was reported in Germany on a floor of spruce wood by Huckfeldt and Schmidt (2013), was not found in the present study.

Donkioporia expansa is not as well-known as other wood-destroying fungi, but its occurrence in Germany and Austria is gaining in importance. In Europe, there are reports from England, Czech Republic, Slovakia, Belgium, France and Germany. It was declared ,important wood-destroying fungus in buildings" between 1990 and 1999 (Kleist and Seehann 1999; Bobekova et al. 2008). D. expansa prefers moist to wet wood, decays hard- and softwoods by white rot and is found consequently mainly in wet rooms as kitchens and bathrooms (Kleist and Seehann 1999). Pfabigan (2011) reported on a case of damage due to massive dampness in the ceiling below a kitchen and a desolate shower. This fungus occurs mainly in coniferous wood, but it can also infest the duramen of oakwood. (Schmidt 2010).

Investigations indoors show that other wood-destroying fungi are involved as well. Many species are also found in Styria, and the occurrence of some of them is documented in the database for fungi (Dämon and Krisai-Greilhuber 2012). The genus Leucogyrophana prefers wooden farmhouses and floors in historical buildings in this study. In Norway, Leucogyrophana holds $3 \%$ of the total number of wood-destroying fungi (Alfredsen et al. 2005). L. pinastri, found under boards during a survey, was even blamed to be the cause of an extrinsic allergic alveolitis (Stone et al. 1989). L. pulverulenta causes brown rot and occurs regularly in German buildings with earthy, wet substrates (Huckfeldt et al. 2011).

The distribution range of Fomes fomentarius corresponds widely to the appearance of deciduous trees. In the present study, it was found in an attic. Fomitopsis sp. may destroy wood when stored improperly (Rayner and Boddy 1988; Schwarze et al. 1999). In this study, Fomitopsis pinicola was isolated from a floor. F. pinicola grows on hard- and softwood in all regions in Styria (Maurer et al. 2014). F. pinicola was also isolated from buildings in Estonia (Plank 1979). In Italy, it was found only outdoors (Saitta et al. 2011).

Rhodonia placenta, which was introduced from North America, appeared in the present studies once in a wooden hut made of spruce timber (Findlay 1967). An infestation of the floor and the thermal insulation with wood chips in a new timber frame building by $R$. placenta was reported from Germany just a few years after residents moved in (http:// www.holzfragen.de/seiten/rosafarbener_saftporling.html). $R$. placenta is very common in North America and serves 
as a model organism for brown rot decay mechanism and comparative genome analysis (Gaskell et al. 2017).

Tapinella (Paxillus) panuoides is also present on coniferous wood. It grows on bridges, balconies, garden furniture or together with S. lacrymans in cellars, stables etc. (Schmidt 1994). In the present study, T. panuoides was found in the cellar of a farmhouse, and T. hirsuta in the attic of a singlefamily house and in the ceiling of a rectory. Tapinella spp. are not only present in Styria but also in the neighboring federal state of Carinthia (Sperdin 1976). Wilcox and Dietz (1997) described the prevalence of Rhodonia placenta, $T$. panuoides and other wood-destroying fungi on freshly cut wood. These fungi were possibly brought into the wood during processing or after flooding (Heidegger-Kastenhuber 2007).

In Europe, the genus Trametes is represented by nine species (Tomsovsky et al. 2006). Trametes spp., above all $T$. trogii, are residents of deciduous wood in moist riparian forests, also in Germany (Kreisel 1962). Whereas T. trogii was found in the present study in wall- and ceiling constructions, T. abietina was isolated from the roof of the wet zone of a sauna. T. trogii was also found in Graz in the floor of a new building.

The ochre crust fungus (Crustoderma dryinum) was discovered first in southwestern Germany after a water damage (Grimm et al. 2016). C. dryinum was also reported sporadically from Scandinavia, France and the Austrian federal state Tyrol (Dämon 2001). In the present study, it was identified only once on the wooden ceiling of a house with water damage.

Species like Stereum hirsutum, which may infest older and weakened trees, can also be introduced into buildings (Blinkova and Ivanenko 2016). Cease et al. (1989) discovered Scytalidium sp. in the wood of a birch and confirmed the interaction between Scytalidium sp. and brown and white rot fungi. In the present study, Scytalidium lignicola grew in an attic and a ceiling.

Polyporus spp. were found sporadically in a wooden ceiling, floor and roof terrace, Tapinella panuoides in the bathroom of a single-family house, Resinicium bicolor in the floor of a single-family house and the attic of an apartment building, and Trechispora farinacea in a wooden ceiling and on incorrectly stored timber.

\section{Conclusion}

Wood-destroying fungi in buildings are present in all regions of the federal state of Styria, with a prevalence for buildings in the urban area and properties constructed before 1945 . The most common species is the dry rot fungus Serpula lacrymans, which is found in all types of buildings and in all Styrian regions. More work and above all active cooperation and networking between scientific institutions and commercial companies focused on wood-destroying fungi in buildings must be done to increase the knowledge in this subject.

Acknowledgements Open access funding provided by Medical University of Graz. We are grateful to the late Prof. Dr. Helmut Salomon, whose extensive and meticulous collection of cases of wood-destroying fungi in Styria was the cornerstone for this paper, which we would like to dedicate to him.

Open Access This article is distributed under the terms of the Creative Commons Attribution 4.0 International License (http://creativeco mmons.org/licenses/by/4.0/), which permits unrestricted use, distribution, and reproduction in any medium, provided you give appropriate credit to the original author(s) and the source, provide a link to the Creative Commons license, and indicate if changes were made.

\section{References}

Alfredsen G, Solheim H, Jenssen KM (2005) Evaluation of decay fungi in Norwegian buildings. Int Res Group Wood Prot IRG/ WP 05-10562:1-12

Bavendamm W (1969) Der Hausschwamm und andere Bauholzpilze [The dry rot and other wood-destroying fungi]. Gustav Fischer, Stuttgart

Behling G (2004) Der Echte Hausschwamm: Vorkommen, Risiken, Schäden und Bekämpfungsmassnahmen [The real dry rot fungus: Occurrence, risks, damages and control measures]. FLUGS Fachinformationsdienst, GSF Forschungszentrum für Umwelt und Gesundheit, Helmholtz Zentrum, Munich. http://www.gsf.de/flugs . Accessed 02 Jul 2018

Blinkova O, Ivanenko O (2016) Communities of tree vegetation and wood-destroying fungi in parks of the Kyiv city, Ukraine. Lesn Cas For J 62:110-122

Bobekova E, Tomsovsky M, Horacek P (2008) Application of molecular genetic methods for identification of wood-decaying fungi in wood constructions. Acta Univ Agric Silvic Mendelianae Brun $56: 281-284$

Brunner W (1989) Bomben auf Graz [Bombs on Graz]. Leykam, Graz

Buchwald G (1989) Über das Vorkommen von Serpula lacrymans (Wulf.: Fr.) Schröter in der Bundesrepublik Deutschland [On the occurrence of Serpula lacrymans (Wulf.: Fr.) Schröter in the Federal Republic of Germany]. Z Mykol 56:79-86

Cease KR, Blanchette RA, Highley TL (1989) Interactions between Scytalidium species and brown- or white-rot basidiomycetes in birch wood. Wood Sci Technol 23:151-161

Dämon W (2001) Die corticoiden Basidienpilze des Bundeslandes Salzburg (Österreich). Floristik, Lebensräume und Substratökologie [The corticoid basisiomycetes of the province of Salzburg (Austria). Floristics, natural habitats and ecology of substrate]. Bibliotheca Mycologica 189. J. Cramer, Berlin, Stuttgart

Dämon W, Krisai-Greilhuber I (2012) Die Datenbank der Pilze Österreichs [The database of Austrian fungi]. Stapfia 96:245-330

Dämon W, Forstinger H, Maurer W, Scheuer Ch (2000) Holzabbauende Pilze in der Steiermark [Wood-destroying fungi in Styria]. III. Mitt Naturwiss Ver Steiermark 130:43-70

Engh IB, Carsen T, Saetre GP, Högberg N, Dois S, Kauserud H (2010) Two invasive populations of the dry rot fungus Serpula lacrymans show divergent population genetic structures. Mol Ecol 19:706-715

Findlay WPK (1967) Timber pests and diseases. Pergamon, Oxford 
Gabriel J, Svec K (2017) Occurrence of indoor wood decay basidiomycetes in Europe. Fungal Biol Rev 31:212-217

Gardes M, Bruns TD (1993) ITS primers with enhanced specificity for basidiomycetes - application to the identification of mycorrhizae and rusts. Mol Ecol 2:113-118

Gaskell J, Kersten P, Larrondo LF et al (2017) Draft genome sequence of a monokaryotic model brown-rot fungus Postia (Rhodonia) placenta SB12. Genom Data 14:21-23

GBIF: The Global Biodiversity Information Facility (2017). http:// www.gbif.org/species/8769913. Accessed 02 Jul 2018

Gistl R (1946) Einführung in die Biologie des Bauens. Gebäudeschädigende Mikroorganismen, ihre Erkennung und Bekämpfung [Introduction into the biology of constructing. Building damaging microorganisms, their detection and combating]. Ferdinand Enke, Stuttgart

Grimm K, Huckfeldt T, Schmidt O (2016) Die Ockerfarbene Krustenhaut (Crustoderma dryinum), ein besonderer Braunfäule-Erreger in Gebäuden [The „Ockerfarbene Krustenhaut“ (Crustoderma dryinum), a particular cause of brown rot in buildings]. Z Mykol $82: 85-110$

Grosser D (1985) Pflanzliche und tierische Bau- und Werkholzschädlinge [Plant- and animal based pests on timber]. DRW, Leinenfelden-Echterlingen

Heidegger-Kastenhuber A (2007) Folgeschäden an Holzkonstruktionen im Hausbau durch das Hochwasser 2002 im Donautal, Kamptal und Kremstal [Consequential damages on wooden building constructions by the 2002 flood in the valleys of the rivers Danube, Kamp and Krems]. Diploma thesis, University of Natural Resources and Life Sciences (Boku), Vienna

Held BW, Blanchette RA (2017) Deception Island, Antarctica, harbors a diverse assemblage of wood decay fungi. Fungal Biol 121:145-157

Högberg N, Land CJ (2004) Identification of Serpula lacrymans and other decay fungi in construction timber by sequencing of ribosomal DNA—a practical approach. Holzforschung 58:199-204

Huckfeldt T, Schmidt O (2013) Coniophora prasinoides (Bourdot \& Galzin) Bourdot \& Galzin-Erstfund für Deutschland [Coniophora prasinoides (Bourdot \& Galzin) Bourdot \& Galzin- the first find in Germany]. Z Mykol 79:443-454

Huckfeldt T, Schmidt O (2015) Hausfäule- und Bauholzpilze [Woodand timber-destroying fungi], 2nd edn. Rudolf Müller, Köln

Huckfeldt T, Dill I, Steeghs-Alcer K, Schmidt O (2011) Morpho-anatomische und molekulare Charakterisierung des Hausfäulepilzes Leucogyrophana pulverulenta [Morpho-anatomical and molecular characterisation of the wood rotting fungus Leucogyrophana pulverulenta]. Z Mykol 77:45-60

Hyde KD, Hatmi AMS, Andersen B, Boekhout T, Buzina W, Dawson TL Jr, Eastwood DC, Gareth Jones EBG, de Hoog S, Kang Y, Longcore JE, McKenzie EHC, Meis JF, Pinson-Gadais L, Rathnayaka AR, Richard-Forget F, Stadler M, Theelen B, Thongbai B, Tsui CKM (2018) The world's ten most feared fungi. Fungal Divers 93:161-194

Irbe I, Andersone I (2009) Wood decay fungi in Latvian buildings including cultural monuments. In: Proceedings of the international conference held by COST Action IE0601 in Braga (Portugal), 5-7 November 2008, pp 94-100

Kalcher HK (2004) Feuchtigkeitsschäden im Haus. Ursachen erkennen, Schäden beseitigen [Moisture damages in buildings. Recognition of causes, elimination of damages]. Eberhard Blottner, Taunusstein-Wehen

Kauserud H (2004) Widespread vegetative compatibility groups in the dry rot fungus Serpula lacrymans. Mycologia 96:232-239

Kauserud H, Högberg N, Knudsen H, Elborne SA, Schumacher T (2004) Molecular phylogenetics suggest a North American link between the anthropogenic dry rot fungus Serpula lacrymans and its wild relative $S$. himantioides. Mol Ecol 13:3137-3146
Kauserud H, Svegarden IB, Saetre GP, Knudsen H, Stensrud O, Schmidt O, Doi S, Sugiyama T, Högberg N (2007) Asian origin and rapid global spread of the destructive dry rot fungus Serpula lacrymans. Mol Ecol 16:3350-3360

Kleist G, Seehann G (1999) Der Eichenporling, Donkioporia expansa-ein wenig bekannter Holzzerstörer in Gebäuden [The "Eichenporling", Donkioporia expansa-a less known wooddestroyer in buildings]. Z Mykol 65:23-32

Koch AP (1991) The current status of dry rot in Denmark and control strategies. In: Jennings DH, Bravery AF (eds) Serpula lacrymans. Wiley, Chichester, pp 147-154

Kreisel H (1962) Trametes extenuata und Trametes trogii in Deutschland. (Trametes extenuata and Trametes trogii in Germany) (In German). Ber bay bot Ges 35:55-56

Krieglsteiner GJ (1991) Verbreitungsatlas der Großpilze Deutschlands (West) [Distribution atlas of the macrofungi in Germany (west)]. 1A. Ulmer, Stuttgart

Krzisnik D, Lesar B, Thaler N, Humar M (2018) Micro and material climate monitoring in wooden buildings in sub-Alpine environments. Constr Build Mater 166:188-195

Maurer W, Dämon W, Forstinger H, Petrine L, Scheuer Ch (2009) Holzabbauende Pilze der Steiermark [Wood-decaying fungi in Styria]. V Joannea Botanik 7:9-34

Maurer W, Scheuer Ch, Aron A (2013) Pilze auf Holz-Ökologie und Verbreitung in der Steiermark [Fungi on wood-ecology and distribution in Styria]. Joannea Botanik 10:67-92

Maurer W, Friebes G, Scheuer Ch (2014) Pilze auf Holz-Ökologie und Verbreitung in der Steiermark [Fungi on wood-ecology and distribution in Styria]. Joannea Botanik 11:35-75

Maurice S, Coroller L, Debaets S, Vasseur V, Floch GL, Barbier G (2011) Modelling the effect of temperature, water activity and $\mathrm{pH}$ on the growth of Serpula lacrymans. J Appl Microbiol 111:1436-1446

Mayrhofer H (2006) Holzzerstörende Pilze in Innenräumen [Wooddestroying fungi in the interior]. In: Symposium Pilze im Innenraum [Fungi in the interior], Graz, pp 78-81

Paajanen L, Viitanen H (1989) Decay fungi in Finnish houses on the basis of inspected samples from 1978 to 1988. IRG/WP/ 1401:4

Palfreyman JW (2001) The domestic dry rot fungus, Serpula lacrymans, its natural origins and biological control. Ariadne Workshop, Prague, Czech Republic. http://www.arcchip.cz/w08/w08_ palfreyman2.pdf. Accessed 02 Jul 2018

Palfreyman JW, Gartland JS, Sturrock J, Lester D, White NA, Low GA, Bech-Andersen J, Cooke DEL (2003) The relationship between "wild" and "building" isolates of the dry rot fungus Serpula lacrymans. FEMS Microbiol Lett 228:281-286

Pfabigan N (2011) Holzzerstörende und holzverfärbende Pilze [Wooddestroying and wood-discoloring fungi]. In: Tagungsband Wiener-Holzschutztage [Conference proceeding Vienna days of wood protection] 2011, Holzforschung Austria, pp 27-36

Pilt K, Oja J, Pau K (2009) The wood-destroying fungi in buildings in Estonia. In: Brebbia CA (ed) Structural studies, repairs and maintenance of heritage architecture XI. WIT Press, Ashurst, pp 243-251

Plank S (1979) Areale holzabbauender Pilze im Burgenland [Areas of wood-destroying fungi in Burgenland]. BFB-Bericht 33:65-75

Pottier D, Andre V, Roult JP, Bourreau A, Duhamel C, Bouchart VK, Richard E, Guibert M, Verte P, Garon D (2014) Airborne molds and mycotoxins in Serpula lacrymans-damaged homes. Atmos Poll Res 5:325-334

Rayner ADM, Boddy L (1988) Fungal decomposition of wood; its biology and ecology. Wiley, Chichester

Saitta A, Bernicchia A, Gorjón SP, Altobelli E, Granito VM, Losi C, Lunghini D, Maggi O, Medardi G, Padovan F, Pecoraro L, Vizzini A, Persiani AM (2011) Biodiversity of wood-decay fungi in Italy. Plant Biosyst 145:958-968 
Schmidt O (1994) Holz- und Baumpilze. Biologie, Schäden, Schutz, Nutzen [Wood and tree fungi. Biology, damages, protection and benefit]. Springer, Berlin

Schmidt O (2000) Molecular methods for the characterization and identification of the dry rot fungus Serpula lacrymans. Holzforschung 54:221-228

Schmidt O (2007) Indoor wood-decay basidiomycetes: damage, causal fungi, physiology, identification and characterization, prevention and control. Mycol Prog 6:261-279

Schmidt O (2010) Wood and tree fungi. Springer, Berlin

Schmidt O, Huckfeldt T (2011) Characteristics and identification of indoor wood-decaying basidiomycetes. In: Adan OCG, Samson RA (eds) Fundamentals of mold growth in indoor environments. Wageningen Academic Publishers, Wageningen, pp 117-180

Schmidt O, Grimm K, Moreth U (2002) Molekulare und biologische Charakterisierung von Gloeophyllum-Arten in Gebäuden [Molecular and biological characterization of Gloeophyllum-species in buildings]. Z Mykol 68:141-152

Schwarze FWMR (2007) Wood decay under the microscope. Fungal Biol Rev 21:133-170

Schwarze FWMR, Engels J, Mattheck C (1999) Holzzersetzende Pilze in Bäumen [Wood destroying fungi in trees]. Rombach, Freiburg im Breisgau

Singh J (1999) Dry rot and other wood-destroying fungi: their occurrence, biology, pathology and control. Indoor Build Environ $8: 3-20$

Skrede I, Engh IB, Binder M, Carlsen T, Kauserud H, Bendiksby M (2011) Evolutionary history of Serpulaceae (Basidiomycota): molecular phylogeny, historical biogeography and evidence for a single transition of nutritional mode. BMC Evol Biol 11:230-243

Sperdin F (1976) Pilzvorkommen in Kärnten: Kremplingartige und Schmierlinge [Occurrence of fungi in Carinthia: „Kremplingartige“ and „Schmierlinge“]. Carinthia II 169(89):163-165

Statistik Austria (2018) https://www.statistik.at/. Accessed 02 Jul 2018

Sterflinger K (2010) Fungi: their role in deterioration of cultural heritage. Fungal Biol Rev 24:47-55
Stone CA, Johnson GC, Thornton JD, Macauley BJ, Holmes PW, Tai EH (1989) Leucogyrophana pinastri, a wood decay fungus as a probable cause of an extrinsic allergic alveolitis syndrome. Aust NZ J Med 19:727-729

Thornton JD (1991) Australian scientific research on Serpula lacrymans. In: Jennings DH, Bravery AF (eds) Serpula lacrymans. Wiley, Chichester, pp 155-171

Tomsovsky M, Kolarik M, Pazoutova S, Homolka L (2006) Molecular phylogeny of European Trametes (Basidiomycetes, Polyporales) species based on LSU and ITS (nrDNA) sequences. Nova Hedwigia 82:269-280

Watkinson SC, Eastwood DC (2012) Serpula lacrymans, wood and buildings. Adv Appl Microbiol 78:121-149

Weir JR (1919) Concerning the introduction into the United States of extra-limital wood-destroying fungi. Mycologia 11:58-65

Weiss B, Wagenmüller A, Kruse K (2000) Beschreibung und Bestimmung von Bauholzpilzen [Description and identification of timber fungi]. DRW Weinbrenner, Leinfelden-Echterdingen

White NA, Low GA, Singh J, Staines H, Palfreyman W (1997) Isolation and environmental study of "wild" Serpula lacrymans and Serpula himantioides from the Himalayan Forests. Mycol Res 101:580-584

White NA, Dehal PK, Duncan JM, Williams NA, Gartland JS, Palfryman JW, Cooke DEL (2001) Molecular analysis of intraspecific variation between building and "wild" isolates of Serpula lacrymans and their relatedness to $S$. himantioides. Mycol Res 105:447-452

Wilcox WW, Dietz M (1997) Fungi causing above-ground wood decay in structures in California. Wood Fiber Sci 29:291-298

Publisher's Note Springer Nature remains neutral with regard to jurisdictional claims in published maps and institutional affiliations. 